\title{
Frugivory and potential of birds as dispersers of Siparuna guianensis
}

\author{
Gonçalves, VF. ${ }^{a *}$, Silva, AM. ${ }^{a}$, Baesse, CQ. ${ }^{a}$ and Melo, C. ${ }^{a}$ \\ anstituto de Biologia, Universidade Federal de Uberlândia - UFU, Campus Umuarama, \\ Bloco 2D, sala 28, CEP 38400 902, Uberlândia, MG, Brazil \\ *e-mail: vanessinha_fg@hotmail.com
}

Received: July 4, 2013 - Accepted: December 12, 2013 - Distributed: May 31, 2015

(With 1 figure)

\begin{abstract}
Siparuna guianensis is a neotropical tree species, found both on edge and interior of forest fragments, mainly on understory and regeneration areas. The fruit are zoochorous with a sweet aril. This work aims to determine the bird species that eat the fruits of $S$. guianensis in a semi deciduous forest fragment in Brazilian Cerrado and measure which species have the highest potential as seed dispersers. Seven individuals of $S$. guianensis were sampled, totaling 69 hours. A hundred and fifty four visits were registered by seven species of birds. Antilophia galeata had the biggest potential as seed dispersal agent. Antilophia galeata, Lanio penicillatus and Dacnis cayana can be important seed dispersers, since they have a high consumption and visitation rate. The consumption of $S$. guianensis by species of different feeding guilds can be an important strategy for dispersal of plant species in regeneration habitats, raising the chances of an effective dispersal.
\end{abstract}

Keywords: cerrado, forest regeneration, fruit-eating birds, seed dispersal, semidecidual forest.

\section{Frugivoria e potencial de aves como dispersores de Siparuna guianensis}

\section{Resumo}

Siparuna guianensis é uma espécie arbórea neotropical do Cerrado, encontrada tanto na borda quanto no interior de fragmentos florestais, principalmente no sub-bosque de matas em regeneração. Os frutos são zoocóricos com arilos adocicados. Os objetivos desse estudo foram: determinar quais espécies de aves consomem os frutos de $S$. guianensis em um fragmento de floresta semidecídua do Cerrado brasileiro, e inferir quais espécies apresentaram maior potencial de dispersão. Sete indivíduos de S. guianensis foram amostrados, totalizando 69 horas-planta. Foram registradas 153 visitas, realizadas por sete espécies de aves. Antilophia galeata apresentou o maior potencial de dispersão. Entre as espécies exclusivamente florestais, A. galeata, Dacnis cayana e Lanio penicillatus podem ser importantes dispersores, devido à taxa de consumo elevada, maior número de visitação e maior potencial para dispersar as sementes em sítios viáveis de germinação. O consumo dos frutos de S. guianensis por espécies de diferentes guildas alimentares pode ser uma importante estratégia para esta espécie em ambientes em regeneração, por maximizar a possibilidade de dispersão.

Palavras-chave: cerrado, regeneração florestal, aves frugívoras, dispersão de sementes, floresta semidecidua.

\section{Introduction}

Seed dispersal is a process that exerts control over the density and distribution of plants in a range of environments (Fuentes, 2000), influencing colonization and maintenance of species diversity (Wang and Smith, 2002). In tropical environments up to $90 \%$ of plant species have fruit dispersed by animals (Howe and Smallwood, 1982),

Birds are important seed dispersal agents, mainly in understory (Gentry, 1982), where they have an important role in forest regeneration (Jordano et al., 2006). In the tropics, birds are among the main dispersers of tree pioneers species, being important in the early establishment of communities (Duncan and Chapman, 1999). Moreover, they contribute to the deposition of seeds in disturbed habitats (Wunderle, 1997) and initiation of secondary succession (Charles-Dominique, 1986).

Frugivorous birds are adapted to track, select, feed and digest fruit (Corlett, 2011). Among the neotropical frugivorous Passeriformes, Pipridae and Contigidae are the most specialized (Fleming and Kress, 2011). However, species of these families are rare in most parts of the Brazilian Cerrado (Bagno and Marinho-Filho, 2001; Marçal-Júnior et al., 2009), where the seed dispersal is done mainly by generalists and opportunist species (Gottsberger and Silberbauer-Gottsberger, 2006).

Several factors determine the efficiency of a bird species as a seed disperser, like gape width (Wheelwright, 1985), visit frequency (Vázquez et al., 2005), time that 
the bird remained on the fruit-bearing plant (Pratt and Stiles, 1983), fruit handling behavior (Levey, 1988), gut transit time (Herrera, 1984) and post foraging movement (Westcott and Graham, 2000; Jordano et al., 2006). Due to these factors, different species of frugivorous birds have different efficiency in seed dispersal and environmental regeneration (Schupp, 1993).

This work aims to evaluate the potential of birds as dispersers of Siparuna guianensis in a semi deciduous forest fragment in central Brazil.

\section{Material and Methods}

\subsection{Study area}

The study was conducted in a 37 ha semi deciduous forest fragment $\left(18^{\circ} 57^{\prime} 03\right.$ " S; $48^{\circ} 12^{\prime} 22^{\prime}$ W) in the municipality of Uberlândia, in central Brazil. The forest has around 96 tree species and a canopy of 15 to $20 \mathrm{~m}$ (Araújo and Haridasan, 1997). The climate in the region is classified as $A w$ according to Köppen, with rainy summer and dry winter (Rosa et al., 1991).

\subsection{Study specie}

Siparuna guianensis Aublet (Siparunaceae) is a woody species that occurs on the edge and in the interior of Cerradão, mainly in the understory (Oliveira and Felfili, 2005). This specie has a fruit with sweet aril that is very attractive to birds, which are its main seed dispersers (Valentini et al., 2010a). This specie is important because of its medicinal components used to treat stomach disorders, malaria, fevers and colic (Valentini et al., 2010b).

\subsection{Phenology}

A monthly phenological monitoring for $S$. guianensis was made between February 2011 and January 2012, covering the rainy and dry season. In a $400 \mathrm{~m}$ transect with $4 \mathrm{~m}$ width, 2 m on each side (Arantes, 2002; Melo et al., 2003), 10 individuals of $S$. guianensis bearing fruit were tagged and monitored. For each individual the fruit phenophase was registered, being noted the presence / absence of green and ripe fruit. A fruit was considered ripe when the ariled seed was exposed.

\subsection{Frugivory and seed dispersal}

Observations by plant-focal method were conducted in seven individuals of $S$. guianensis during April 2011. The observation sections occurred early in the morning (06:30h-10:30h) and afternoons (15:30h-17:30h), using a $8 \times 40 \mathrm{~mm}$ binoculars. The observers remained $10 \mathrm{~m}$ distant from the focal tree so as to not disturb bird visits.

For each effective visit (visit together with fruit consumption): (1) bird species; (2) number of fruits taken; (3) time that the bird spent on the plant, classified as: " 1 " $-<1$ min, " 2 "- $>1$ min and $<2$ min, " 3 "- $>2$ min and $<$ $3 \mathrm{~min}$, "4"- $>3 \mathrm{~min}<$ and $4 \mathrm{~min}$, " 5 "- $>4 \mathrm{~min}$; and (4) handling behavior, classified according to Schupp (1993) as: "swallow" - ingestion of the whole fruit, without damaging the seed; "bite" - taking out part of fruit aril; and "smash" - fruit consumption with seed damage were registered. The avifauna was taxonomically classified according to CBRO - Cômite Brasileiro de Registros Ornitlógicos (CBRO, 2011), in relation to the feeding guild (Motta-Júnior and Lombardi, 1990; Sick, 1997), to forest dependence (“dependent", "semi-dependent" and "independent"), and in relation to sensibility to habitat disturbance: "low", "medium" and "high" sensibility (Stotz et al., 1996).

The dispersal potential (DP), which measures the efficiency of a species as seed dispersers from the number of fruit taken and time spent on visits, was calculated for each bird species as follows (Equation 1):

$$
D P=\frac{f}{t} . n
$$

being, $f$ the mean number of fruits ingested undamaged per visit; $t$ the mean time that the bird remained on the fruitbearing plant; $n$ the number of effective visits per hour.

\section{Results}

The fruiting period of Siparuna guianensis concentrated during the months of February, March and April.

Sixty nine (69) hours of observation were conducted in Siparuna guianensis, registering the consumption of fruit by seven bird species, all Passeriformes of four different families (Table 1). The Thraupidae family was represented by four species. Fifty seven per cent $(n=4)$ of the bird species registered are dependent of forest environments. In relation to the sensibility to habitat disturbance, no species was considered as highly sensitive, two were considered medium sensitive and all the others were low sensitive. Antilophia galeata was the only frugivorous bird, all the others were classified as omnivores.

A hundred and fifty three (153) effective visits were registered, two hundred and forty two (242) ariled seeds being taken, giving a mean of $1.6+1.3$ fruit per visit. The peak of visitation was concentrated between 09:00 and 09:30 (Figure 1). Antilophia galeata made 41.83\% $(n=64)$ of the total visits and consumed more than $42 \%$ $(\mathrm{n}=91)$ of the fruit. Saltator similis was the second most frequent species $(21.26 \% ; \mathrm{n}=27)$, followed by Lanio penicillatus $(20.47 \% ; \mathrm{n}=26)$ and Dacnis cayana $(18.90 \%$; $\mathrm{n}=24)$. The most used handling behavior was "swallow" (48.36\%) and bite (34.64\%).

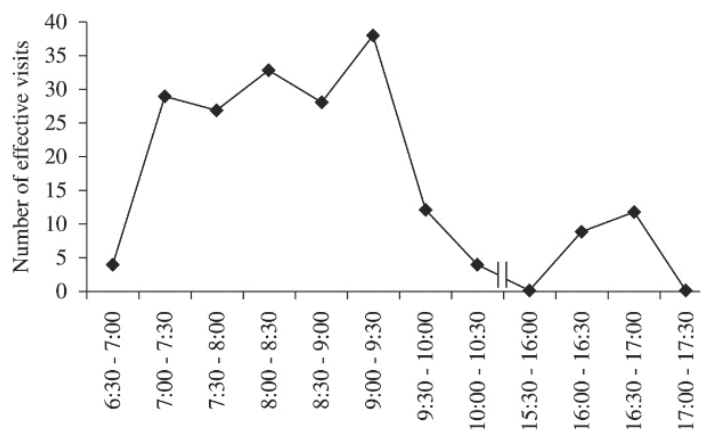

Figure 1. Number of effective visits by birds per hour. 
Table 1. Description of bird species that consumed Siparuna guianensis fruit.

\begin{tabular}{|c|c|c|c|c|c|c|}
\hline Taxon & Diet & FD & Sen & Handling behavior ( $n$ of fruit eaten) & Visit rate & DP \\
\hline \multicolumn{7}{|l|}{ Pipridae } \\
\hline Antilophia galeata & $\mathrm{F}$ & $\mathrm{D}$ & M & SW (48), SM (16) & 0.78 & 0.4788 \\
\hline \multicolumn{7}{|l|}{ Turdidae } \\
\hline Turdus leucomelas & $\mathrm{O}$ & SD & $\mathrm{L}$ & SW (2) & 0.03 & 0.0145 \\
\hline \multicolumn{7}{|l|}{ Thraupidae } \\
\hline Saltator similis & $\mathrm{O}$ & SD & $\mathrm{L}$ & SM (27) & 0.39 & - \\
\hline Lanio penicillatus & $\mathrm{O}$ & $\mathrm{D}$ & $\mathrm{L}$ & SW (6), B (20) & 0.22 & 0.0593 \\
\hline Tersina viridis & $\mathrm{O}$ & $\mathrm{D}$ & $\mathrm{L}$ & B (1) & 0.01 & - \\
\hline Dacnis cayana & $\mathrm{O}$ & SD & $\mathrm{L}$ & SW (15), B (9) & 0.35 & 0.1213 \\
\hline \multicolumn{7}{|l|}{ Emberezidae } \\
\hline Arremon flavirostris & $\mathrm{O}$ & D & M & SW (3), B (7) & 0.07 & 0.0114 \\
\hline
\end{tabular}

Diet: O - omnivorous, F - frugivorous. Forest dependence (FD): D - forest dependent, SD - forest semi-dependent, I - forest independent. Sensibility to habitat disturbance (Sen.): M - medium, L - low. Handling behavior: SM - smash, SW - swallow, B bite. Visit rate: number of visits per hour. Dispersal Potential (DP): see methods.

\section{Discussion}

Siparuna guianesis offers ripe fruits between December and April, at the end of the rainy season and the beginning of the dry season (Approbato and Godoy, 2006). This strategy allows the plant to attract dispersers, increasing the chance of seed dispersal (Melo et al., 2003). This dependence on dispersal agents is related, in some cases, with the increase of seed survival and establishment of seedlings over great distances from the mother plant (Murali, 1997).

Siparuna guianensis is a species of early secondary succession (Higuchi et al., 2006). Its fruit have small seeds $(10 \mathrm{~mm})$ and are produced in large quantities, which can result in a large removal rate and colonization in open areas (Francisco and Galetti, 2002). There is a functional relationship between the fruit size and the body size of frugivores (Kantak, 1979), e.g., small fruit $(<10 \mathrm{~mm})$ facilitate the accessibility by birds with different sizes (Melo et al., 2003), increasing fruit consumption. Gomes (2013) found this functional relationship between beak size and fruit size in seasonal forests in Cerrado.

Frugivorous birds are sensitive to habitat disturbance, especially the larger species (Gomes et al., 2004). The loss of some frugivorous species can have a detrimental impact on the composition of plant communities (Silva and Tabarelli, 2000). The low sensitivity to habitat disturbance observed in the fruit consumers of $S$. guianesis can be due to the conservation status of the habitats in which these species occur. In disturbed habitats there is a domain of less sensitive and generalist species, which are responsible for seed dispersal in these habitats.

The method used to measure dispersal potential provides a comparative index between the different species of fruit-eating birds, taking into account factors such as consumption rate, time spent and visit rate. In spite of this index not considering pos-feeding factors, such as gut transit effects and place of seed deposition, it can be useful to measure the quantitative component of seed dispersal (Schupp et al., 2010)
Antilophia galeata can be an important seed disperser, having the greatest dispersal potential among the fruiteating birds of S. guianensis. Silva and Melo (2011) also registered Antilophia galeata eating fruit of S. guianensis. One of the factors that characterize an effective disperser is that the bird remains on the fruit-bearing plant for only the time necessary to eat the fruit, since a longer foraging time increases the chances of the bird dropping the seeds, defecating or regurgitating, below the parental plant crown (Pratt and Stiles, 1983; Motta-Júnior and Lombardi, 1990).

Moreover, Antilophia galeata, being a frugivore, spends less time and energy foraging than generalist species (Foster, 1977; Melo and Oliveira, 2009), which makes it a better disperser. However, Antilophia galeata, being a territorialist species, may have a long distance dispersion. The male territories are around 1 ha (Marini and Cavalcanti, 1992), favoring the allelophaty and endogamy (Melo and Oliveira, 2009).

Dacnis cayana and Lanio penicillatus, in spite of being omnivorous, also have a high dispersal potential. Fruit consumption by generalist species is very common in Brazilian Cerrado (Macedo, 2002; Gottsberger and Silberbauer-Gottsberger, 2006; Silva and Melo, 2013), and is important for seed dispersal and regeneration of disturbed environments, since it excludes dependence on specialists frugivorous (Guedes et al., 1997). The generalists species cover a greater area while foraging among plants of the same and different species, carring seeds away from the parental plant and, consequently, allowing the seeds to escape competition and density-dependant mortality (Guedes et al., 1997; Melo and Oliveira, 2009).

Siparuna guianensis fruit were consumed by species of different feeding guilds and habitat use. This can be an important strategy for species that occur in regenerating environments, due to the fact of being less selective in relation to disperser birds, increasing the chances of effective seed dispersal. 


\section{Acknowledgements}

We are very grateful for CAPES - Brazil and CNPQ Brazil for financial support and Daniella R. F. Teles and Luis Paulo Pires for helpful comments on this manuscript.

\section{References}

APPROBATO, AU. and GODOY, SAP., 2006. Levantamento de diásporos em áreas de cerrado no Município de Luiz Antônio, SP. Hoehnea, vol. 33, p. 385-401.

ARANTES, AA., 2002. Florística, fitossociologia e fenologia do estrato herbáceo-arbustivo de um gradiente florestal no Triângulo Mineiro. Rio Claro: Universidade Estadual Paulista. 213 p. Tese de Doutorado em Biologia Vegetal.

ARAÚJO, GM. and HARIDASAN, M., 1997. Estrutura fitossociológica de duas matas mesófilas semidecíduas, em Uberlândia, Triângulo Mineiro. Acta Botanica Brasilica, vol. 19 , no. 4, p. 801-811.

BAGNO, MA. and MARINHO-FILHO, J.,2001. A avifauna do Distrito Federal: uso de ambientes abertos e florestais e ameaças. In RIBEIRO, JF., FONSECA, CEL. and SOUSA-SILVA, JC. (Eds.). Cerrado: caracterização e recuperação de matas de galeria. Brasília: Embrapa. p. 495-528.

CHARLES-DOMINIQUE, P., 1986. Inter-relations between frugivorous vertebrates and pionner plants: Cecropia, birds and bats in French Guiana. In ESTRADA, A. and FLEMING, TH. (Eds.). Frugivorous and seed dispersal. Brunoy: Dr W. Junk Publish. p. 119-135.. http://dx.doi.org/10.1007/978-94-009-4812-9_12.

Cômite Brasileiro de Registros Ornitlógicos - CBRO. (2011). Listas das aves do Brasil. Available from: $<\mathrm{http}$ ://www.cbro.org. br>. Access in: 25 Fev. 2013.

CORLETT, RT., 2011. Seed dispersal in Hong Kong, China: past, present and possible futures. Integrative zoology, vol. 6, no. 2, p. 97-109. http://dx.doi.org/10.1111/j.1749-4877.2011.00235.x. PMid:21645275

DUNCAN, R. and CHAPMAN, CA., 1999. Seed dispersal and potential forest succession in abandoned agriculture in tropical Africa. Ecological Applications, vol. 9, no. 3, p. 998-1008. http:// dx.doi.org/10.1890/1051-0761(1999)009[0998:SDAPFS]2.0.CO;2.

FLEMING, TH. and KRESS, WJ., 2011. A brief history of fruits and frugivores. Acta Oecologica, vol. 37, no. 6, p. 521-530. http:// dx.doi.org/10.1016/j.actao.2011.01.016.

FOSTER, MS., 1977. Ecological and nutritional effects of food scarcity on a tropical frugivorous bird and its fruit source. Ecology, vol. 58, no. 1, p. 73-85. http://dx.doi.org/10.2307/1935109.

FRANCISCO, MR. and GALETTI, M., 2002. Aves como potenciais dispersoras de sementes de Ocotea pulchella Mart. (Lauraceae) numa área de vegetação de cerrado do sudeste brasileiro. Revista Brasileira de Botânica, vol. 25, p. 11-17.

FUENTES, M., 2000. Frugivory, seed dispersal and plant community ecology. Trends in Ecology \& Evolution, vol. 15, no. 12, p. 487-488. http://dx.doi.org/10.1016/S0169-5347(00)02031-0.

GENTRY, AH., 1982. Pattens of neotropical plant species diversity. Ecology and Evolution, vol. 15, p. 1-84.

GOMES, BZ., MARTINS, FR. and TAMASHIRO, JY., 2004. Estrutura do cerradão e transição entre cerradão e floresta paludícola num fragmento da International Paper do Brasil, Ltda., em Brotas, SP. Revista Brasileira de Botânica, vol. 27, no. 2, p. 249-262.

GOMES, CM., 2013. Interações entre aves e plantas: frugivoria, amplitude de nicho e relações morfológicas em três diferentes ambientes. Uberlândia: Universidade Federal de Uberlândia. Dissertação de Mestrado em Ecologia e Conservação de Recursos Naturais.

GOTTSBERGER, G. and SILBERBAUER-GOTTSBERGER, IM. 2006. Life in the Cerrado: a South American Tropical Seasonal Vegetation. 1st ed. Ulm: Reta Verlag. p. 277. Pollination and seed dispersal, vol. II.

GUEDES, MC., MELO, VA. and GRIFFTH, JJ., 1997. Uso de poleiros artificiais e ilhas de vegetação por aves dispersoras de sementes. Ararajuba, vol. 5, p. 229-232.

HERRERA, CM., 1984. A study of avian frugivores, birddispersed plants, and their interaction in Mediterranean scrublands. Ecological Monographs, vol. 54, no. 1, p. 1-23. http://dx.doi. org/10.2307/1942454.

HIGUCHI, P., REIS, MGF., REIS, GG., PINHEIRO, AL., SILVA, ALPCT. and OLIVEIRA, CHR., 2006. Composição florística da regeneração natural de espécies arbóreas ao longo de oito anos em um fragmento de floresta estacional semidecidual, em Viçosa, MG. Revista Árvore, vol. 30, no. 6, p. 893-904. http:// dx.doi.org/10.1590/S0100-67622006000600004.

HOWE, HF. and SMALLWOOD, J., 1982. Ecology of seed dispersal. Annual Review of Ecology and Systematics, vol. 13, no. 1, p. 201-228. http://dx.doi.org/10.1146/annurev.es.13.110182.001221.

JORDANO, P., GALETTI, M., PIZO, MA. and SILVA, WR.,2006. Ligando frugivoria e dispersão de sementes à biologia da conservação. In DUARTE, CF., BERGALLO, HG., SANTOS, MA., and VA, AE. (Eds.). Biologia da conservação: essências. São Paulo: Editorial Rima. p.411-436.

KANTAK, GE., 1979. Observation on some fruit-eating birds in Mexico. The Auk, vol. 96, p. 183-186.

LEVEY, DJ., 1988. Spatial and temporal variation in Costa Rica fruit and fruit-eating bird abundance. Ecological Monographs, vol. 58, no. 4, p. 251-269. http://dx.doi.org/10.2307/1942539.

MACEDO, RHF.,2002. The Avifauna: ecology, biogeography, and behavior. In OLIVEIRA, PS. and MARQUIS, RJ. (Eds.). The Cerrados of Brazil - Ecology and natural history of a neotropical savanna. New York: University Press. p. 242-265

MARÇAL-JÚNIOR, O., FRANCHIN, AG., ALTEFF, EA., SILVA-JÚNIOR, EL. and MELO, C., 2009. Levantamento da avifauna na reserva ecológica Panga (Uberlândia, MG, Brasil). Bioscience Journal, vol. 5, p. 91-108.

MARINI, MA. and CAVALCANTI, RB., 1992. Mating system of the Helmeted Manakin (Antilophia galeata) in Central Brazil. The Auk, vol. 109, no. 4, p. 911-913. http://dx.doi.org/10.2307/4088172.

MELO, C. and OLIVEIRA, PE., 2009. Frugivory in Lacistema hasslerianum Chodat (Lacistemaceae), a gallery forest understory treelet in Central Brazil. Brazilian journal of biology $=$ Revista brasileira de biologia, vol. 69, no. 1, p. 201-207. http://dx.doi. org/10.1590/S1519-69842009000100027. PMid:19347166

MELO, C., BENTO, EC. and OLIVEIRA, PE., 2003. Frugivory and dispersal of Faramea cyanea (Rubiaceae) in cerrado woody plant formations. Brazilian journal of biology $=$ Revista brasileira de biologia, vol. 63, no. 1, p. 75-82. http://dx.doi.org/10.1590/ S1519-69842003000100010. PMid:12914417 
MOTTA-JÚNIOR, JC. and LOMBARDI, JA., 1990. Aves como agentes dispersores da copaíba (Copaifera langsdorfi, Caesalpinaceae) em São Carolos, Estado de São Paulo. Ararajuba, vol. 1, p. 105-106.

MURALI, KS., 1997. Patterns of seed size, germination and seed viability of tropical tree species in Southern India. Biotropica, vol. 29, no. 3, p. 271-279. http://dx.doi.org/10.1111/j.1744-7429.1997. tb00428.x.

OLIVEIRA, ECL. and FELFILI, JM., 2005. Estrutura e dinâmica da regeneração natural de uma mata de galeria no Distrito Federal, Brasil. Acta Botanica Brasilica, vol. 19, no. 4, p. 801-811. http:// dx.doi.org/10.1590/S0102-33062005000400016.

PRATT, TK. and STILES, EW., 1983. How long fruit-eating birds stay in the plants where they feed: implications for seed. American Naturalist, vol. 122, no. 6, p. 797-805. http://dx.doi. org/10.1086/284172.

ROSA, R., LIMA, SC. and ASSUNÇÃO, WL., 1991. Abordagem preliminar das condições climáticas de Uberlândia (MG). Sociedade e Natureza, vol. 3, p. 91-108.

SCHUPP, EW., 1993. Quantity, quality and the effectiveness of seed dispersal by animals. Vegetatio, vol. 107/108, p. 15-29.

SCHUPP, EW., JORDANO, P. and GÓMEZ, JM., 2010. Seed dispersal effectiveness revisited: a conceptual review. The New Phytologist, vol. 188, no. 2, p. 333-353. http://dx.doi.org/10.1111/ j.1469-8137.2010.03402.x. PMid:20673283

SICK, H., 1997. Ornitologia Brasileira. 2nd ed. Rio de Janeiro: Editora Nova Fronteira. 912 p.

SILVA, AM. and MELO, C., 2011. Frugivory and seed dispersal by the Helmeted Manakin (Antilophia galeata) in forests of Brazilian Cerrado. Ornitologia Neotropical, vol. 22, p. 69-77.

SILVA, AM. and MELO, C., 2013. Overlap and resource sharing in coteries of fruit-eating birds. Journal of Tropical Ecology, vol. 29 , no. 5 , p. $409-416$.
SILVA, JMC. and TABARELLI, M., 2000. Tree species impoverishment and the future flora of the Atlantic forest of northeast Brazil. Nature, vol. 404, no. 6773, p. 72-74. http:// dx.doi.org/10.1038/35003563. PMid:10716443

STOTZ, DF., FITZPATRICK, JF., PARKER III, TA. and MOSKOVITS, DK,. 1996. Neotropical Birds: Ecology and Conservation. Chicago: University of Chicago Press. p. 478

VALENTINI, CMA., RODRÍGUEZ-ORTÍZ, CE. and COELHO, MFB., 2010a. Siparuna guianensis Aublet (negramina): uma revisão. Revista Brasileira de Plantas Medicinais, vol. 12, no. 1, p. 96-104. http://dx.doi.org/10.1590/S1516-05722010000100014.

VALENTINI, CMA., SILVA, LE., MACIEL, EM., FRANCESCHINI, E., SOUSA, PT., DALL'OGLIO, EL. and COELHO, MDB., 2010b. Annual variation of yield and chemical composition of volatile components of Siparuna guianensis Aublet. Quimica Nova, vol. 33, p. 1506-1509. http://dx.doi.org/10.1590/S010040422010000700015 .

VÁZQUEZ, D., MORRIS, WF. and JORDANO, P., 2005. Interaction frequency as a surrogate for the total effect of animal mutualists on plants. Ecology Letters, vol. 8, no. 10, p. 1088-1094. http:// dx.doi.org/10.1111/j.1461-0248.2005.00810.x.

WANG, BC. and SMITH, TB., 2002. Closing the seed dispersal loop. Trends in Ecology \& Evolution, vol. 17, no. 8, p. 379-386. http://dx.doi.org/10.1016/S0169-5347(02)02541-7.

WESTCOTT, DA. and GRAHAM, DL., 2000. Patterns of movement and seed dispersal of tropical frugivore. Oecologia, vol. 122, no. 2, p. 249-257. http://dx.doi.org/10.1007/PL00008853.

WHEELWRIGTH, NT., 1985. Fruit size, gape width, and the diets of fruit-eating birds. Ecology, vol. 66, no. 3, p. 808-818. http://dx.doi.org/10.2307/1940542.

WUNDERLE JUNIOR, JM., 1997. The role animal seed dispersal in accelerating native forest regeneration on degraded tropical-land. Forest Ecology and Management, vol. 99, no. 1-2, p. 223-235. http://dx.doi.org/10.1016/S0378-1127(97)00208-9. 